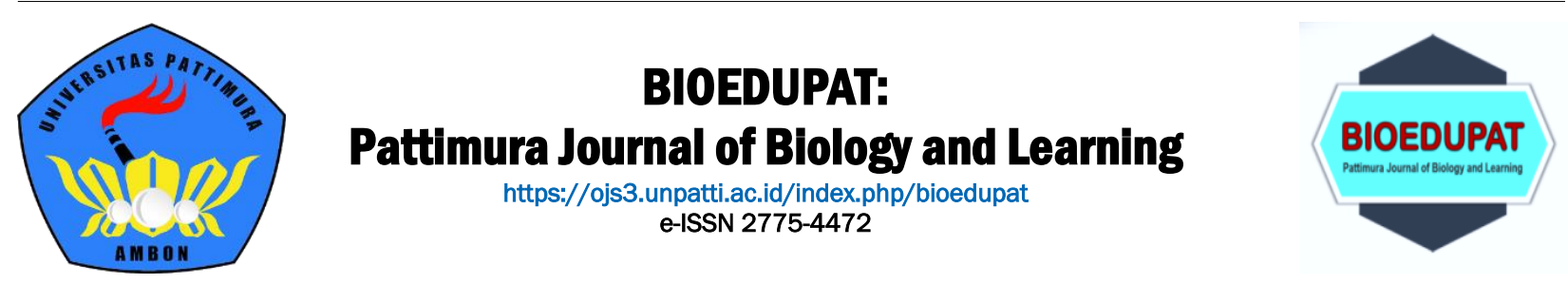

Research Article

\title{
The density of Siasia (Sipunculus nodus) population based on the differences in the substrate of the sea grasses beds on the waters of Saparua Island
}

\author{
Yoin Meissy Matulessy ${ }^{1,{ }^{*}}$, Ali Awan², Sintje Liline ${ }^{2}$ \\ ${ }^{1}$ Postgraduate Student of Biology Education, Pattimura University, \\ JI. Dr. Tamaela, Ambon, Maluku 97114, Indonesia \\ 2 Study Program of Biology Education, Faculty of Teacher Training and Education, Pattimura University, \\ Jl. Ir. M. Putuhena, Ambon, Maluku 97233, Indonesia \\ *corresponding author: matulessy03@gmail.com
}

Received: 17 February 2021

Revised: 15 March 2021

Accepted: 21 April 2021

\begin{abstract}
Sipuncula, a marine biota which is commonly called a peanut worm, is a marine biota that is a little "controversial". Some literature also refers to these animals as "unsegmented marine worms" or unsegmented marine worms. Siasia (Sipunculus nodus) usually lives in coastal areas, especially around seagrass beds, mangrove forests, and coral reefs. These biotas tend to inhabit the bottom of the waters, especially in the substrate, so they are categorized as infauna benthic organisms. Siasia (S. nodus) can inhabit soft and hard substrate areas. Based on its ecological function, seagrass forms associations with various kinds of marine life as food providers, shelters, and places to live, causing high diversity of marine life. The basic substrate in the form of flat stones and gravel is a good living environment for macrozoobenthos because it is rich in organic compounds so it has a big population density and diversity. The bottom of the waters in the form of sand and fine sediment is not a good living environment for benthic animals. Factors affecting density and diversity are environmental conditions, habitat, and diet. The same factors also affect the nutritional content of Siasia (S. nodus). So, it is feared that when the population density of Siasia ( $S$. nodus) becomes high in the water there will be competition for food which will have a direct impact on the nutritional content of Siasia (S. nodus). The population density of each water is different, so it is necessary to research the population density of Siasia (S. nodus) based on differences in the substrate of the seagrass area in the waters of Saparua Island, Maluku Province, Central Maluku Regency. The highest population density value of Siasia (Sipunculus nodus) in Saparua Island waters is found in Siri-sori State and the lowest is in Paperu Country.
\end{abstract}

Keywords: Density, proximate, Sipunculus nodus

To cite this article:

Matulessy, Y. M., Awan, A., Liline, S. (2021).The density of Siasia (Sipunculus nodus) population based on the differences in the substrate of the sea grasses beds on the waters of Saparua Island. Bioedupat: Pattimura Journal of Biology and Learning, Vol 1(1), 11-16.DOl: https://doi.org/10.30598/bioedupatv1i1pp11-16

\section{INTRODUCTION}

Sipuncula, a marine biota commonly called peanut worm, is a marine biota that is a little "controversial" (Silaban \& Silaban, 2019). Some literature also refers to these animals as "unsegmented marine worms" or unsegmented marine worms (Barnes, 1987; Hutching \& Johnson, 2003). Taxonomically, Sipuncula is not included in the Phylum Annelida Class Polychaeta, which is a taxon where the majority of marine worms can be grouped. Sipuncula, also known as Sipunculida (Tree of a life web project, 2008), is a biota that belongs to a 
separate phylum under Kingdom Animalia, namely Phylum Sipuncula. Thus, although it is often called a "worm" the use of this term is still a matter of debate among scientists. The presence of Sipuncula in marine and estuary ecosystems is relatively less well known when compared to the marine worm Polychaeta.

Sipuncula is described at glance as a marine animal that looks like a worm but without segments. Its body is divided into the main body (trunk) and an introvert that can be pulled inward or behind. The ratio of the length of the two parts varies for each type. Sipuncula is a minor phylum in the large bilaterian animal group, namely a group of animals that are triploblastic, bilaterally symmetrical, and formed from three kinds of seed layers (endodermis, mesoderm, and ectoderm (Suwignyo \& Sugiarti, 2005).

Kendari people generally process Siasia (Sipunculus nodus) as a food substitute for fish which is believed to have health benefits and is also used as herbal/natural medicine. Silaban \& Nanlohy (2011) state that marine worms originating from Nalahia waters have the highest protein content of $17.13 \%$. Zhang et al. (2011) state that in China sea worms have long been used as traditional medicine in treating tuberculosis, regulating gastric and spleen functions, as well as restoring health caused by pathogens. Purwaningsih (2014) states that the ethanol extract of sea worms has potential as antidiabetes through in vitro tests which can inhibit the activity of the aglucosidase enzyme by $16-24$ ppm.

Sipuncula of the species ( $S$. nudus) is known mainly in the Maluku region as a food ingredient and as bait to catch fish such as tatu fish and garopa. S. nudus is known as "Siasia" by the people of Ambon Island. On the island of Rhun (Banda Islands) it is called "Kariong" and in the Bangka-Belitung Islands it is called "kekuak". Siasia (S. nodus) on the island of Saparua is used as a coastal water resource for the community. The capture of this biota by the local community has been carried out regularly. Siasia (S. nodus) is one of the biotas that is usually sought after when the seawater recedes by the local community. Usually, Siasia is consumed fresh (kohokoho, the general term for the Maluku people), sautéed, and sauteed with soy sauce. But a lot of people, who never know at all, or know but have never tasted it because the community's knowledge is still very low about the benefits of Siasia (S. nodus).

Silaban (2012) states that Siasia (S. nodus) usually lives in coastal areas, especially around seagrass areas, mangrove forests, and coral reefs. These biotas tend to inhabit the bottom of the waters, especially in the substrate. They have been categorized as infauna benthic organisms. Siasia (S. nodus) can inhabit soft and hard substrate areas. Based on its ecological function, seagrass forms associations with various kinds of marine life as food providers, shelters, and places to live, causing high diversity of marine life (Supono \& Arbi, 2010). The basic substrate in the form of flat stones and gravel is a good living environment for macrozoobenthos because it is rich in organic compounds so that it has great density and diversity (Odum, 1994). Furthermore, Koesbiono (1979) said that the bottom of the waters in the form of sand and fine sediment is an unfavorable living environment for benthic animals.

Factors affecting population density and diversity are environmental conditions, habitat, and diet. The same factors also affect the nutritional content of Siasia (S. nodus). It is feared that when the population density of Siasia (S. nodus) becomes high in the water there will be competition for food which will have a direct impact on the nutritional content of Siasia (S. nodus). The population density of each water is different. So it is necessary to research the population density of Siasia (S. nodus) based on differences in the substrate on the seagrass area in the waters of Saparua Island, Maluku Province, Central Maluku Regency.

\section{METHODS}

\section{Sampling}

This research was conducted for 8 months starting from December 2019 to August 2020. It was carried out in the waters of Saparua Island (Figure 1). Sampling was carried out in several villages, including Paperu Village (rocky), Siri-soriAmalatu Village (rocky sand substrate), Kulur Village (sandy substrate), Ihamahu Village (sandy substrate), and ltawaka Village (rocky sandy substrate).

Sampling is done by using the roaming method. And then observations were made on the surface of the sediment. If there is some kind of dune and the roots of the seagrass are slightly raised, then the Sipuncula usually hides under the area. The bigger the dune that is formed and the roots of the seagrass are lifted, the bigger the body size and vice versa (Silaban \& Silaban, 2019).

When sampling is carried out, positions are plotted using a machete. Then after using a machete, a sample of Siasia (Sipunculus nodus) was taken and was put in a labeled plastic sample. Data collection on the population density of Siasia (S. nodus) was carried out by counting the number of individual animals contained in squares at the research location and also documentation in the form of photographs. 


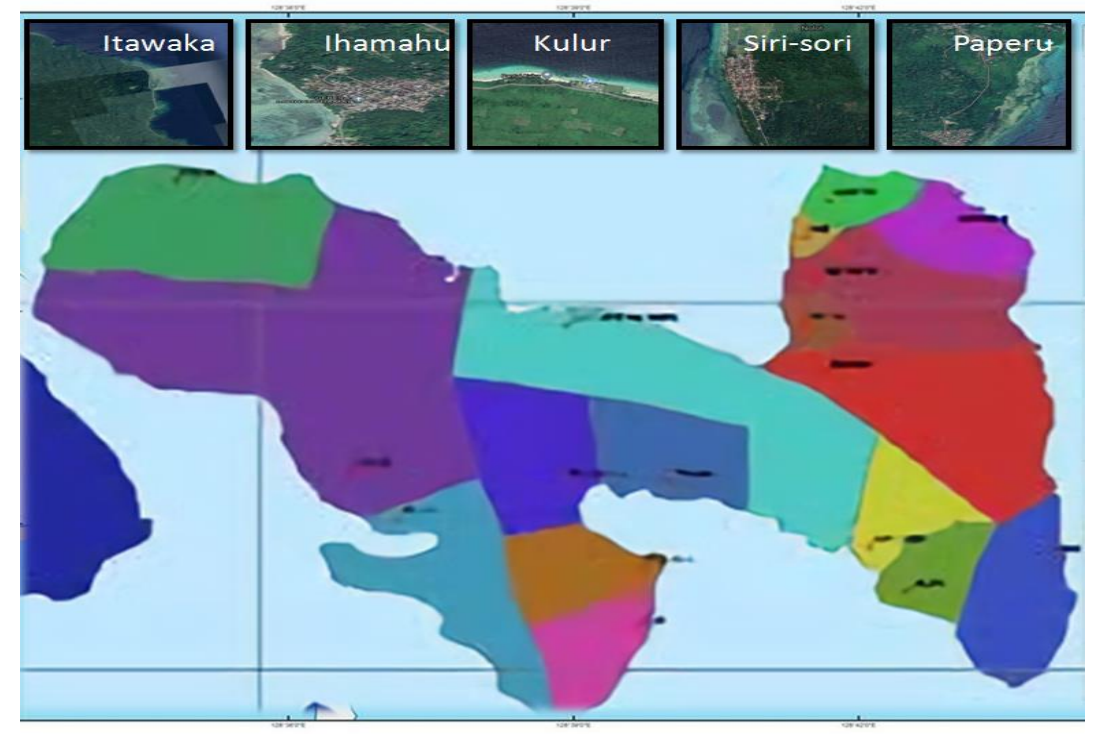

Figure 1. Research Location Map

\section{Population Density Calculation}

The population density of Siasia (Sipunculus nodus) was analyzed using the population density formula (Brower, 1997) as follows:

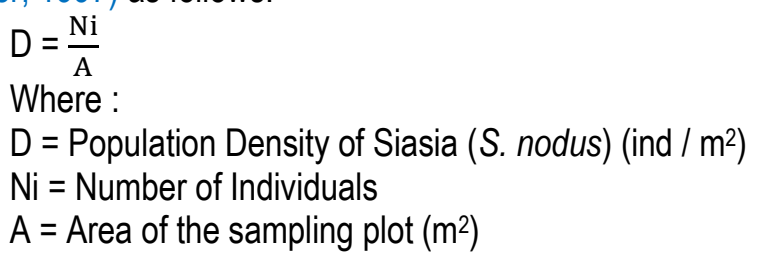

\section{Environmental parameter measurement}

Environmental parameters calculation includes salinity, temperature, $\mathrm{pH}$, and substrate (observed). The tools that were used are thermometer and $\mathrm{pH}$ meter by placing these tools at two different points, namely at the point near the coast of Station 1 (shallow) and the other at a point near the reef of Station 2 (deep). This tool is placed to determine the fluctuation of temperature and light intensity at the research location at a predetermined time range. The salinity meter uses a hand refractometer, where these measurements are carried out three times at each station. Substrate observation was carried out physically by observing the surface of the sediments found in each research location.

\section{RESULTS AND DISCUSSION}

\section{Environmental parameter}

Environmental parameters measured in this study are salinity, temperature, and water $\mathrm{pH}$. The following are the results of environmental parameter measurements in 5 villages (Paperu, Siri-sori Amalatu, Kulur, Ihamahu, and Itawaka) with different substrates in the waters of the island of Saparua, Central Maluku district. The results of environmental parameters can be seen in Table 1.

Table 1. Results of measurements and observations of environmental parameters

\begin{tabular}{lcccc}
\hline \multicolumn{1}{c}{ Location } & Temperature $\left({ }^{\circ} \mathrm{C}\right)$ & Salinity $(\%)$ & pH & Substrate \\
\hline Ihamahu Village & $26.4-28.5$ & $29.8-34.3$ & $7.4-7.7$ & Rocky, sandy \\
Paperu Village & $29.9-36.5$ & $36.5-41.8$ & $7.7-7.9$ & Rocky \\
Itawaka Village & $27.1-29.6$ & $31.1-33.1$ & $7.2-7.6$ & Rocky, sandy \\
Kulur Village & $25.9-27.7$ & $28.3-32.5$ & $7.1-7.5$ & Sandy \\
Siri-sori Amalatu Village & $29.2-35.9$ & $34.9-38.5$ & $7.6-7.8$ & Rocky, sandy \\
\hline
\end{tabular}

\section{Temperature}

Based on measurements made using a thermometer, the results show that the highest temperature is in Paperu, which ranges from $29.9-36.5^{\circ} \mathrm{C}$ and is followed by Siri-sori Amalatu Village with values ranging from $29.2-35.9^{\circ} \mathrm{C}$ The lowest temperature measurement values were in Kulur Village, namely $25.9-27.7^{\circ} \mathrm{C}$ and followed by Ihamahu and Itawaka villages which had temperature measurement values ranging between 26.4- 
28.5 and $27.1-29.6^{\circ} \mathrm{C}$. This is because in the waters of Paperu and Siri-sori Amalatu only a few rivers flow fresh water into the sea. So the temperature value of the water in the 2 villages namely Paperu and Siri-sori Amalatu is higher than the waters in 3 other villages (Ihamahu, Itawaka, and Kulur). The factors that influence the temperature value are rainfall, evaporation, river run-off, and season (Barus, 2004). In general, the temperature range in all research locations (Paperu, Siri-sori Amalatu, Ihamahunltawaka, and Kulur) obtained during the study was tolerable by Siasia (S. nudus). This is because the temperature obtained is below the tolerance limit for the balance of the population structure of benthic animals in general.

According to Effendi (2003), the activity of microorganisms requires different optimum temperatures. Every $10^{\circ} \mathrm{C}$ increase in temperature will increase the decomposition process and oxygen consumption by 2-3 times. However, this increase in temperature is accompanied by a decrease in dissolved oxygen levels so that the presence of oxygen is often unable to meet the oxygen needs of aquatic organisms for metabolism and respiration. According to Ghufran \& Baso (2007) in other words, the higher the water temperature, the lower the solubility of oxygen in the water, and vice versa.The higher the solubility of oxygen, the lower the water temperature. The indirect effect of temperature on the environment is to affect metabolism, the solubility of gases, including oxygen, and various chemical reactions in water. Welch (1980) states that the temperature that is dangerous for macrozoobenthos ranges from $35^{\circ} \mathrm{C}-40^{\circ} \mathrm{C}$.

\section{Salinity}

Based on the results of salinity measurements carried out using a refractometer. The results show that the highest salinity is in Paperu. Which is between 36.5-41.8 \% and followed by Siri-sori Amalatu Village with values ranging from 34.9-38.5\%. The lowest salinity measurement value is in Kulur Village, which is $28.3-32.5 \%$ and is followed by Ihamahu and Itawaka Villages which have salinity measurement values ranging between 29.8-34.3 and $31.1-33.1 \%$. This is because the results of water temperature measurements in 3 Villages: Ihamahu, Itawaka, and Kulur are lower than the water temperatures in 2 other countries, namely Paperu and SirisoriAmalatu so that the evaporation rate is also low. The relationship between evaporation and salinity is directly proportional. The higher the level of evaporation in water, the higher the salinity and vice versa (Nybakken, 1992).

Furthermore, Nybakken (1992) also explained that the fluctuation of salinity in the intertidal area can be caused by two things. Firstly, due to heavy rain so that the salinity will decrease and secondly due to very high evaporation during the day. So, the salinity will be very high. In general, the salinity range in all study locations (Paperu, Siri-sori Amalatu, Ihamahu, Itawaka, and Kulur) obtained during the study was tolerable by Siasia (S. nodus). This is because the salinity obtained is below the tolerance limit for the balance of benthic animal population structures in general.

Mudjiman (1981) states that the salinity range considered suitable for macrozoobenthic life ranges from 15-45 $\%$. The report from Irwan (1997) added that in low and high salinity waters, macrozoobenthos such as snails, worms (Annelida) and shellfish can be found. Payung (2017) states that salinity greatly affects the balance in the body of organisms through changes in water density and changes in osmotic pressure. The higher the salinity, the greater the osmotic pressure so that the organism must have the ability. Adapt to changes in salinity to some extent through osmoregulation mechanisms.

\section{$\mathrm{pH}$}

Based on the results of $\mathrm{pH}$ measurements made using a ph meter, the results have almost the same values from one location to another. The highest $\mathrm{pH}$ measurement value ranged from 7.7-7.9 in Paperu Village while the lowest was between 7.1-7.5 in Kulur Village. Variations in $\mathrm{pH}$ values are influenced by many factors, including temperature, dissolved oxygen, alkalinity, the presence of various anions and cations as well as the type and stage of organisms (Pescod, 1973).

In general, the pH range in all research locations (Paperu, Siri-sori Amalatu, Ihamahu, Itawaka, and Kulur) obtained during the study was tolerable by Siasia (S. nudus). The life of aquatic organisms is greatly influenced by $\mathrm{pH}$ value fluctuations. In general, aquatic organisms are tolerant of a neutral $\mathrm{pH}$ value range. The ideal $\mathrm{pH}$ for aquatic organisms is generally between 7-8.5. Water conditions that are very acidic or very alkaline will threaten the survival of the organism because it will cause metabolic and respiration disorders (Odum, 1994).

\section{Substrate}

Based on the results of substrate observations carried out physically by observing the sediment surface in 5 villages, the results are varied. The substrate that was mostly found is the rocky sandy substrate. It is found in Ihamahu, Itawaka, and Siri-sori Amalatu villages. The least found substrate is the sandy and rocky substrate in Kulur and Paperu villages. Besides the existence of basic substrate organic compounds in the form of flat stones and gravel, it is a good living environment for macrozoobenthos so that it has great population density and 
diversity (Odum, 1994). Furthermore, Koesbiono (1979) said that the bottom of the waters in the form of sand and fine sediment is not a very good living environment for benthic animals.

According to Seki (1982), the main organic components found in water are amino acids, proteins, carbohydrates, vitamins, and hormones which are also found in water. Only $10 \%$ of the organic material settles as a substrate to the bottom of the water. The basic substrate is the main factor affecting the life, development and diversity of macrozoobenthos (Hynes, 1976).

\section{Population density}

The results of the calculation on the population density of Siasia (Sipunculus nodus) in the waters of the island of Saparua show quite varied values. The results of observing the presence of individuals in each village can be seen in Table 2. The results of calculating the density of Siasia (S. nodus) can be seen in Table 3.

Table 2. Observations of the presence of individuals in each villages

\begin{tabular}{lccccccccccccc}
\hline \multicolumn{1}{c}{ Location } & \multicolumn{1}{c}{ Number of Individuals in Squares to } & \multicolumn{1}{c}{ Total of Individuals } \\
\cline { 2 - 11 } & $\mathbf{1}$ & $\mathbf{2}$ & $\mathbf{3}$ & $\mathbf{4}$ & $\mathbf{5}$ & $\mathbf{6}$ & $\mathbf{7}$ & $\mathbf{8}$ & $\mathbf{9}$ & $\mathbf{1 0}$ & $\mathbf{1 1}$ & $\mathbf{1 2}$ & \\
\hline Ihamahu & 1 & - & 2 & 1 & - & 1 & 2 & 2 & 1 & - & - & 1 & 11 \\
Paperu & - & 2 & 1 & - & 2 & - & - & 1 & - & 1 & 1 & - & 8 \\
Itawaka & 2 & - & 1 & 2 & 2 & 1 & 2 & 2 & 2 & 2 & 3 & 2 & 21 \\
Kulur & 1 & 1 & 1 & 2 & 1 & 1 & 3 & 1 & 1 & 2 & 1 & - & 15 \\
Siri-sori Amalatu & 3 & 2 & 2 & 3 & 1 & 2 & 2 & 1 & 3 & 2 & 2 & 1 & 24 \\
\hline
\end{tabular}

Table 3. Population density calculation result

\begin{tabular}{lcc}
\hline \multicolumn{1}{c}{ Location } & Subtrate Type & Value \\
\hline Ihamahu & Rocky, sandy & 1.21 \\
Paperu & Rocky & 0.89 \\
Itawaka & Rocky, sandy & 2.32 \\
Kulur & Sandy & 1.67 \\
Siri-sori Amalatu & Rocky, sandy & 2.67 \\
\hline Total & & 8.76 \\
\hline
\end{tabular}

Based on the population density calculation results that have been obtained, each location shows different values. The total value of the 5 research locations is 8.76 ind $/ \mathrm{m}^{2}$. The highest value was in Siri-sori Amalatu Village which had a value of 2.67 ind $/ \mathrm{m}^{2}$ and was followed by Itawaka Village with a value of $2.32 \mathrm{ind} / \mathrm{m}^{2}$. The lowest density calculation value was found in Paperu Village with a value of 0.89 ind $/ \mathrm{m}^{2}$ and followed by Ihamahu Village with a value of 1.21 ind $/ \mathrm{m}^{2}$. For 1 other village, namely Kulur, it has a value close to lhamahu Village, which is 1.67 ind / $\mathrm{m}^{2}$.

This difference occurs due to environmental conditions that do not support the life of the S. nodus, diet, type of substrate, and capture. In addition, other activities that can damage the seagrass ecosystem which can have an impact on the population density of $S$. nodus is the local community making the research location a place for boats to dock, the activities of catching gastropods and other marine animals which are carried out at low tide which are mentioned by the local community as "bameti" and tourism / recreational activities such as swimming. One of the activities of the ship that is suspected of destroying the seagrass is the entry and exit of ships into the coastal area. Tourism activities such as swimming on the beach are also thought to damage the seagrass. In contrast to the existing research station in Siri-Sori Amalatu Village which is quite far from residential areas so that no community activity is found, this makes seagrass cover still well preserved and the opportunities for fishing are less, this is shown in the condition of the sediment surface which is still awake.

\section{CONCLUSION}

Based on the results and discussion stated, it can be concluded that: The population density value of Siasia (Sipunculus nodus) in the waters of the island of Saparua shows quite a large difference. The highest population density value is in Siri-soriAmalatu Village and is followed by Itawaka Village. Meanwhile, the lowest population density calculation value was found in Paperu Village and followed by Ihamahu Village. For 1 other country, Kulur has a value that is close to the Ihamahu Village.

\section{REFERENCES}

Barnes, R. D. (1987). Invertebrete zoologi. Edisi ke-5. Sounders College Publising, Orlando, New York. pp. 893. 
Barus, T. A. (2004). Faktor-faktor lingkungan abiotik dan keanekaragaman plankton sebagai indikator kualitas perairan danau toba (Environmental abiotic factors and the diversity of plankton as water quality indicators in lake toba, North Sumatera, Indonesia). Jurnal Manusia dan Lingkungan, 11(2), 64-72. (In Indonesian).

Brower, J., \& Zar, J. (1997). Field and laboratory methods for general ecology. Spiral- bound, USA.

Effendi, H. (2003). Telaah kualitas air bagi pengelolaan sumber daya dan lingkungan perairan [study of water quality for management of aquatic resources and environment]. Kanisius, Yogyakarta. (In Indonesian).

Gufran, M. H., \& Baso, B. T. (2007). Pengelolaan kualitas air dalam budi daya perairan [Management of water quality in aquaculture]. Rineka Cipta, Jakarta. (In Indonesian).

Hutching, P. A., \& Johnson, R. T. (2003). Australian aphroditidae (Polychaeta) delta database. In R.S. Wilson, P.A. Hutchings dan C.J. Glasby (eds). Polychaetes: An Interactive Identification. Csiro, Melbourne.

Hynes, H. B. N. (1976). The ecology with of running water. Lipverpool University Press, England.

Irwan, D. (1997). Prinsip-prinsip ekologi dan organisasi ekosistem \& komunitas lingkungan [Ecological principles and organization of environmental ecosystems \& communities]. Bumi Aksara, Jakarta. (In Indonesian).

Koesbiono. (1979). Dasar-dasar ekologi umum [General ecology basics]. Sekolah Pasca Sarjana Program Studi Lingkungan, IPB. Bogor. (In Indonesian).

Mudjiman, A. (1981). Budidaya udang windu [Tiger prawn cultivation]. PT. Penebar Swadaya, Jakarta. (In Indonesian).

Nybakken, J. W. (1992). Biologi laut suatu pendekatan ekologis [Marine biology an ecological approach]. PT. Gramedia Pustaka Utama, Jakarta. (In Indonesian).

Odum, E. P. (1994). Dasar-dasar ekologi [Ecological basics]. Edisi Ketiga. Universitas Gadjah Mada Press, Yogyakarta. (In Indonesian).

Payung, W. R. (2017). Keanekaragaman makrozoobentos (epifauna) pada ekosistem mangrove di sempadan sungai tallo kota makassar [Diversity of macrozoobenthos (epifauna) in the mangrove ecosystem on the tallo riverbank of the city of Makassar]. Skripsi. Departemen IImu Kelautan Fakultas IImu Kelautan dan Perikanan Universitas Hasanuddin Makassar. (In Indonesian).

Pescod, M. B. (1973). Investigation of rational effluent and stream standart for tropical countries, AIT, Bangkok.

Purwaningsih, S. (2014). Pengembangan pangan fungsional sebagai antidiabetes dari beberapa moluska yang mempunyai aktivitas antioksidan tinggi [Development of functional food as antidiabetic of several mollusks which have high antioxidant activity]. Institut Pertanian Bogor, Bogor. (In Indonesian).

Seki, H. (1982). Organic Material in Aquatik Ecosystem. CRC Press. Inc, Folrida.

Silaban, B. (2012). Profil Nutrisi Sipuncula (Cacing Kacang); Biota laut yang kontrovertif di Pulau Nusalaut, Maluku Tengah [Nutritional Profile of Sipuncula (Peanut Worm); Controversial marine life on Nusalaut Island, Central Maluku]. Laporan hasil penelitian dosen pemula yang dibiayai dengan PNBP Lembaga Penelitian Universitas Pattimura. (In Indonesian).

Silaban, B, br., Nanlohy, E. E. E. M. (2012). Profil nutrisi sipuncula (cacing kacang) biota laut yang kontrovertif di pulau Nusalaut, Maluku Tengah. Jurnal Triton, 7(2):32-41. (In Indonesian).

Silaban, B., \& Silaban, R. (2019). Cacing kacang (sipuncula): Kajian biologi, ekologi, penangkapan dan pemanfaatan [Peanut worms (sipuncula): Study of biology, ecology, capture and use]. CV. Budi Utama, Yogyakarta. (In Indonesian).

Supono., U. Y., \& Arbi. (2010). Struktur komunitas ekhinodermata di padang lamun perairan kema, Sulawesi Utara [Structure of Echinoderm Community in Kema Seagrass Field, North Sulawesi]. Oseanologi dan Limnologi di Indonesia, 6(3), 329-342. (In Indonesian).

Suwignyo., \& Sugiarti. (2005). Avertebrata Air [Aquatic Invertebrates]. Jilid 1, Swadaya, Jakarta. (In Indonesian).

Tree of Life Web Project. (2008). Sipuncula. Peanut Worms. Version 09 January 2008 (temporary). http://tolweb.org/Sipuncula/2487/2008. 01.09 in The Tree of Life Web Project, http://tolweb.org/ [13 Maret 2021].

Welch, E. B. (1980). Ecological Effect of Wastewater. Cambridge University Press, Cambridge London, New York New Rochelle.

Zhang, C. X., Zi, R. D., Qiu, X. C. (2011). Anti inflammatory and anti-nociceptive activities of Sipunculus nudus L. Extract. Journal of Ethnopharmacology, 137(3), 1177-1182. 